\title{
IDENTIFICATION OF THE IMPACT OF GLOBALIZATION ON THE DEVELOPMENT OF ACCOUNTING METHODOLOGY
}

\author{
Tetiana Osadcha ${ }^{1}$ \\ Kherson State University, Ukraine \\ Sergii Bardash ${ }^{2}$ \\ Kyiv Cooperative Institute of Business and Law, Ukraine
}

\begin{abstract}
The relevance of the research consists in the significant lag behind the economies of post-Soviet countries from countries of the world, which play the role of driving forces of global economic globalization. Incomplete transformation of the institution of property rights, including the rights to specific factors of production, distorted perception of the state participation in the regulation of economic relationships, cause a fragmentary reflection of facts of business life of business units by the accounting system. This shortcoming can be eliminated by identifying the advantages, feasibility of the counterstand and measures to involve the economy of Ukraine into the process of economic globalization, as well as determining the priority trends of the transformation of the property institution with the subsequent revision of the accounting methodology. The purpose of the research was to identify the impact of globalization on the development of accounting methodology due to institutional changes in property ownership in the field of management and outline the prerequisites for recognizing the rent as an accounting object. The methodological basis of the research is the dialectical method of knowledge of the essence, preconditions, and consequences of economic globalization as a whole, as well as for its individual subjects; general scientific methods of scientific knowledge (analysis, abstraction, synthesis, generalization) of possible influence of fundamentals and ideas of institutional theory, agency theory, and rent theory on the accounting methodology in order to outline grounds for recognizing the rent as a component of the income of a business unit. Scientific results. It is established that the development of globalization processes was accompanied by significant transformations of property relations and changing approaches to the analysis of activities, in particular, with regard to the use of resources, distribution and redistribution of income. Solving the problems associated with qualitative characteristics of accounting information depends on the implementation of accounting principles, in particular, the principle of the predominance of substance over form. The possibility of its practical application depends on the implementation of the fundamentals and ideas of institutional theory, agency theory and rent theory at the level of the accounting methodology. The stated approach will precondition a certain change in the economic status of a business unit, making it the owner or user of resources, taking into account the availability of certain elements of property rights, and will provide grounds for consideration of economic processes associated with the use of certain resources, the manifestation of rental relations, and the recognition of the income from them as a rent. Taking into consideration the fact that rent is one of the factors of production, theoretical researches in this field should be considered as a basis for research of trends of accounting development, in particular, as to the principles and criteria for recognition of income and assets. The practical significance of the research consists in the development of an income accounting methodology and the determination of financial results of the economic activity, as well as the formation of information support for analysing business unit competitiveness and determining its financial sustainability. Significance/originality. The obtained scientific results will form the prospects for further researches, which will consist in identifying the legal preconditions for rent accounting and determining the trends of the transformation of the property institution. This will contribute to the significant social and economic development of countries whose economies have long been in the command and administrative management format, as well as to the legal recognition of the actual economic preconditions for rent accounting.
\end{abstract}

Key words: globalization, property institution, accounting methodology, agency theory, rent.

JEL Classification: M41, P4, Q2

Corresponding author:

${ }^{1}$ Department of Economics, Finance and Entrepreneurship, Kherson State University.

E-mail: tatiana@osadcha.com

${ }^{2}$ Department of Finance, Banking and Insurance, Kyiv Cooperative Institute of Business and Law.

E-mail: serg.bardash@gmail.com 


\section{Introduction}

Over the past half-century, the development of the economic relationship is under the influence of globalization processes. The development and use of information and computer technologies and their internationalization are taking place. The growth of gross private capital flows, volumes of gross direct foreign investments, an increase in the share of direct foreign investments in the gross formation of constant capital, their accumulation in GDP, the extent of international trade are observed. The share of value added in GDP created by foreign affiliates and the share of persons employed in foreign affiliates in total employment is constantly increasing. On this basis, the economic activity of transnational corporations is intensified.

Analysing these and other global economic processes at the level of expert organizations, one can assess the degree of integration of a particular country into the global economy, the index of transnationalization, the index of readiness for the operation in global networks, and otherindicators of economicglobalization. However, the effects of these trends on the internal economic processes of the business entity on the management subsystems, in particular, on the accounting subsystem, are still insufficiently investigated. The novelty of the research is the hypothesis, which consists in the assumption of the partial use of the methodological potential of accounting for the necessity to improve the competitiveness of the Ukrainian economy under the conditions of irreversible world globalization. The purpose of the research is to identify the impact of globalization on the development of accounting methodology due to institutional changes in ownership rights in the field of management and recognition of the rent as a subject of accounting. Achieving the determined purpose will allow improving the information support for making managerial decisions at the macro and micro level as to distribution and redistribution of incomes, the part of which is the rent.

\section{The state of coverage of the essence of globalization and its impact on the Ukrainian economy}

J. Barton, A.S. Halchynskyi, B.V. Hubskyi, J. Galbraith, D. Meadows, A. Toynbee, E. Toffler, J. Stiglitz, A.K. Subotin, J. Forrester, T. Friedman, O. Spengler, Y.V. Yakovets and others devoted their researches to the problems of globalization processes. Some aspects of the impact of the globalization manifestations on accounting are set out in the researches of S.F. Holov, H.H. Kireitsev, S.F. Lehenchuk, O.M. Petruk, and others. At the same time, they are more concerned with the issues of harmonization and prospects for further development. Unnoticed is the problem of transformation of the institutional environment, changes in the nature of economic processes, property relations that are system-forming for the business entity, as they transform essentially their activities requiring changes in the methodology of accounting as a subsystem of management.

Accounting is an information management subsystem with a wide range of opportunities to achieve specific tasks that are put before it by users of accounting information with various economic and social interests. To the end that this information subsystem fulfils the tasks that it was charged with, it must be properly organized taking into account the factors of both external and internal business environment.

At the end of the twentieth century, the economy of Ukraine was influenced by a new powerful global process, which was named globalization. This is about a social and economic process, in which geographic boundaries of social and economic, as well as cultural systems disappear, and the population is increasingly aware of the disappearance of these borders. In recent years, this concept has become even more popular in connection with the increasing interdependence of regions and developing scientific and technological progress. At the beginning of the twenty-first century, there were more than 40 thousand financial-industrial groups and transnational corporations (TNC) in the world (Subotin, 2004). According to the experts' estimate, this figure may approach to 50 thousand by 2020. "If we will take into account the so-called "mini TNCs", then all of them now already account for more than 65 thousand" (Subotin, 2004). The presented scales and multivariate globalization make it clear that humanity has entered a new era of its development, which will have the character of planetary changes.

For the first time, J. McLean used the term "globalization" was in his papers in 1981, and the American sociologist R. Robertson determined it later in his papers of 1983-1992 (Chub, 2008). Under globalization, they consider the process of expanding and deepening the interdependence of countries in all modern spheres of public life. At the present stage, it covered a system of values, religious, cultural, and ideological systems, technology, as well as political formations, that is, there is a significant change in the institutional environment that requires an adequate adaptation of the accounting methodology.

In the papers of A. Toynbee, I. Wallerstein, F. Braudel, the starting point of globalization is the beginning of the 1500s. First of all, its start is associated with great geographical discoveries (discovery of America by C. Columbus in 1492, the sea route from Europe to India by Vasco da Gama in 1498, the first round-theworld voyage by F. Magellan). "Starting from the 1500s," notes A. Toynbee, "people began to live under one roof" (Halchynskyi, 2009).

However, according to A. Halchynskyi, the year of 1500 should be considered not as a start, but as the beginning of one of the cyclical stages of globalization. 
The planetary nature of human creative activity was inherent (of course, in other forms) in the preceding epochs too. Humankind had the universality signs at the early stages of its development. The well-known American scientist J. Knight writes, "globalization - the growth of global the interdependence - is virtually as old as the history of humankind" (Halchynskyi, 2009).

The second stage of globalization is the establishment of a world system, which fulfils itself on the principles of system integrity, interdependence of its structural components based on the vertical subordination, their gradual homogenization, loss of individual definitions and subordination to integral quality (Halchynskyi, 2009).

In our opinion, being of the Ukrainian economy in a state of transformation without a well-defined strategy and tactics of social and economic development makes the state an inertial object of globalization.

The ambiguous effects of the reforms carried out that directly or indirectly affect the national economy are the causes of ever-increasing efforts to reinterpret the conceptual frameworks of transformation and to develop their effective course towards the future. Assessing the results already achieved, as well as those declared to be achieved in the medium term, it should be noted that the hopes of reducing the gap between Ukraine and the EU countries because of reforms do not yet form a sufficient confidence either in social and economic or technological terms. Preserving the tendencies of production primitivization and de-intellectualization of labour deprives Ukraine of the prospect of becoming a progressive economic state, which provides sufficiently high consumer standards for its population. Such a conversion involves development, which is combined with a decrease in the burden on the natural environment, with the expansion of the economy, to the leading roles in which human capital and information technologies pretend. Unreadiness for such a development of the socioeconomic system that has been formed over the past 15 years is one of the main factors of the potential success-failure of reforms.

One of the most fundamental issues of economic reform is the issue of the driving forces of transformations. Since civil society in Ukraine is still forming, and this process is long enough, there is not yet the question of its leading role. Due to historical circumstances, two leading modernization agents have been formed in Ukraine. This is the state that continues to initiate measures to reform the national economy and the large-scale business that arose in the process of these reforms.

In recent years, domestic scientists have conducted many studies on the feasibility and methods of entering the economic system of Ukraine into a globalized economic space, because these issues are extremely relevant for one of the most economically developed countries of the former USSR. However, there is no straight answer to the above-formulated questions in the papers [(Budkin, 2006; Hubskyi, 2003; Mazur, 2002; Filipenkov, 2002; Shcherbyna, 2001), because the worldview of the authors on the phenomenon under study has significant differences. At the same time, the issues of economic globalization became extremely relevant for Ukraine, as domestic scientists considered the change in its economic system, its entry into a permanent crisis, and the lack of a strategy for its development as a kind of panacea for a significant improvement in the social and economic situation of Ukraine.

At present, under the "globalization" phenomenon is understood:

- the degree of economic integration (volume of international trade, international investments, and various payments crossing customs borders);

- personal contacts (international trips and tourism, volumes of international telephone conversations, mailed items and postal money order, etc.);

- technology (number of Internet users, number of secure Internet servers, etc.);

- involvement in international politics (membership in international organizations, number of embassies, etc.).

The definition of the essence of globalization, its forms and principles are connected with a fundamental scientific polemic, which is aggravated by the political, financial, and ideological nature of problems behind it. The presence of these problems causes a subjective re-estimation or underestimation of the real significance of globalization in the modern world. This statement should not be understood as a denial of the phenomenon itself and its significance. Both are objectively available but are clarified artificially and one-sidedly" (Petruk, 2005). However, the objective content of globalization is the processes heterogeneous in their origin, spheres of manifestation, mechanisms, and consequences. This approach determines the consideration of globalization as a qualitatively independent, complex system of phenomena and relations, integral in its systemic, but contradictory internally.

At the heart of globalization is economic globalization, which is considered by individual scientists as a gradual destruction of the national state with the subsequent loss of economic sovereignty (Economic Encyclopaedic Dictionary). Sovereign states are increasingly evaluating their vulnerability not in relation to each other but in relation to the forces that are behind their control. This thesis is because the manifestation of globalization is the interaction of national and global social processes, the gradual restriction of national peculiarities and their subordination to the system of global relations, laws, and consistent patterns of such interaction, the integrity of which is provided by supranational structures.

One of the signs of economic globalization is the economic integration of national economies - the close 
approaching and the gradual unification of national economic systems into some international metasystems within the framework of integration economic groups. However, it should be noted that the integration of the national economy of Ukraine is incomplete since now its objective economic basis is not formed - the internationalization of the technological method of production, including the internationalization of productive forces and technical and economic relations. The technological mode of production in Ukraine at the beginning of the XXI century is based mainly on the machine and manual labour, which, in view of the intensive development of automated production in the developed countries of the world, threatens its economic sovereignty. Thus, the share of high-tech products in Ukraine in 2003 was only 4-6\%, while in the world GDP - about 40\% (Economic Encyclopaedic Dictionary).

Therefore, Ukraine needs to achieve a high level of competitiveness of the national economic system for an effective entry into the global market. However, based on the results of 2016, Ukraine occupies only the 81st position out of 137 ranking countries in the Global Competitiveness Index. In our opinion, one of the most important indicators that make it possible to identify the national economy as an object and, therefore, an outsider of the globalization process, is that there is a "single stable trend over the past 10 years - a reduction of Ukraine's share in world GDP: almost by 2 times over 10 years" (Nikolaenko).

It should be noted that the above problems, including those that do not allow the national economy to rise significantly in the Global Competitiveness Index, are not the consequences of global economic globalization, they are the consequences of those reforms of government management and the national economy that should be carried out in the near future.

The world economic globalization is an inevitable global economic process, but its mandatory nature does not eliminate the problems caused by its implementation. Its positive effects are undeniable, but equally indisputable and harmful consequences that it carries in any sphere of human life. If the positive effects include the opening of new markets for goods, works, services of a national producer, the free movement of both labour force and tourists, the deepening of cultural exchange, as well as the strengthening of geopolitical influence on the regional and world scene, then the exacerbation of the following problems should be considered as negative effects: corruption, ecology, and economic crime, as well as the threat to national interests and national security, the problems of the fuel and energy complex, which are extremely relevant to most countries of the world community. However, its main harmful effect is the deepening of the division into countries with advanced technologies and the countries, in which the environmentally hazardous production is concentrated, or those, which are destined to remain raw material appendages of the first. As a result of such a division, the property differentiation, the difference in the material security of the population, the difference in levels and quality of life are deepening.

Therefore, now Ukraine faced the challenge of determining further participation in world integration processes and strategies for further social development. However, existing subjectivity and the lack of clear guidelines in its domestic and foreign policy, imposing ineffective models of interstate cooperation damaged significantly the authority of the state, which forced the President of Ukraine, as well as the legislative government to choose: to limit their ambitions to preserve national sovereignty and to accept the economic intervention of transnational corporations and transnational banks in the domestic market, providing appropriate guarantees for investments or, remaining in the outsider social and economic development, to continue manipulating social consciousness by trying to implement the ideals borrowed from the Western democracies. However, taking into consideration the determinacy of the world global integration and the geopolitical situation of Ukraine, it cannot remain aside from these processes. In case of delay in the definition of clear prospects and ways of the transformation of society, a significant delay in the legal rationing of emerging social relations, it cannot be involved in these processes from the "back-door entrance" (Nevmerzhytskyi, 2008).

\section{Relationship of globalization with the accounting methodology}

It is important to note that rationalization, standardization, unification relate to the organization and regulation of property relations, which are key to solving the problem of resource allocation and, therefore, create the greatest number of risks for the activities of key players in a global relationship, which are the transnational corporations.

On this basis, most researchers who deal with accounting problems conclude that globalization means the incorporation, unification of international accounting standards. As a result, the task is to eliminate the contradictions that currently exist between international and national standards, but during their solving, differences in the phases of development of national and international economic systems, which manifest themselves in the principles of organization and functioning of the business entities, in particular, both at the level of theory and at the level of practice are not taken into account in the majority of cases.

At present, this concerns differences in the levels of development of property relations in a particular economic system caused both by the objective factors of historical development, and by the factor of implementation of the provisions of the theory 
of property rights in organization and regulation of economic relations. For example, the criterion of recognition of objects, which demanded possession of ownership of it operated for a long time in Ukraine at the level of accounting methodology.

Another approach provides for the study of new accounting objects that arise under the influence of globalization. However, there is an unnoticed shift in the nature of economic relations that cause to look differently at the subject of accounting and its objects, in particular, to note what new processes and relationships need to be reflected.

The elaborated system of agreements and contractual relations, which was used as an economic basis for the organization of accounting, cannot be applied to such objects as social capital, intellectual capital and other types of capital that are intangible and play a decisive role in ensuring the effectiveness of activities under conditions of global competition. In particular, it concerns a conceptual approach to the recognition and distribution of revenues from their use in the process of carrying on business activities.

It is possible to resolve these and other problems connected with changes in the nature of the use of resources, changes in the formation of incomes and their distribution, generated by globalization, due to improved accounting methodology, in particular, use of the principle of the prevalence of the substance over form. This hypothesis is based on the fact that this principle should be considered as an embodiment of the transformation of emphasis and approaches to building economic relations and trends of rationalization peculiar to globalization.

P.L. Suk relates the principle of "prevalence of the substance over form", first of all, with the globalization of the economy, arguing that it is fundamental. "Its isolation took place in the process of development of market relations, which found their manifestation in the theory of the owner, firm and business entity. The deepening of corporate relations separates the business owner from the management of the legal entity established by him" (Suk, 2011).

A similar conclusion was made by T. Kucherenko, because in the opinion of the author, the segregation of the principle of the predominance of the substance over form occurred in the process of evolutionary development of capital as the basis of commoditymoney relations, the beginning and the continuation of market forms of management, which was manifested in the theory of the owner and the theory of the business unit (a firm) (Kucherenko, 2010).

It is worth recognizing that today there is no consensus on what the idea of the predominance of substance over form is. There is even less unity in answering the question about its implementation, taking into account the fact that its legislative consolidation in the system of regulatory accounting did not produce the expected results. Perhaps the reason is the fact that, as B.I. Valuev states, "The principles were simply transferred to practice from one accounting manual from the USA translated in Russia”. However, we believe that the reason is deeper and is associated with economic traditions and the state of implementation of the fundamental provisions of the theory of property rights, the theory of rent, and agency theory in the management practice.

S.M. Bychkova, N.V. Generalova, S.F. Holov, S.F. Lehenchuk, A.V. Ozeran, B. Rutherford, Y.V. Sokolov, P.L. Suk and others devoted certain attention to the problem of implementing the idea of the predominance of substance over form in the accounting methodology.

The predominance of substance over form as reworded by the IFRS-Conceptual Framework that existed before 2010 was presented as a part of the qualitative characteristics of the financial reporting and was considered as one of its fundamental provisions. "In accordance with this principle, in the presentation of events and operations, the accountant should primarily be guided by the content of the transaction, rather than its drawing-up. Literally, in paragraph 35 of the Principles of Compilation of Financial Statements, the following is stated: "If the information should truly represent transactions and other events, it is necessary that they are accounted in accordance with their content and economic reality and not only their legal form." In this document, the idea of the predominance of substance over form is presented as one of the components of the qualitative characteristics of reliability (Generalova, 2011).

In the modern context of doing business, the gradual introduction of the American version of using the concept of the predominance of substance over form in the formation of a converged conceptual framework of accounting, according to which its existence is not denied, however, at the same time, there is no need to distinguish it. The chosen approach provides for understanding the predominance of substance over form as an integral part of the fair presentation of financial statements (Lehenchuk, 2011). That is, despite the fact that the new wording of this document does not classify the relevant rule as a fundamental principle, its observance is mandatory in determining assets, liabilities or equity. In assessing them, it is necessary to pay attention to substance and economic reality, and not only to their legal form.

Thus, in accordance with Clause 4.12 of the Conceptual Foundations of Financial Framework (Conceptual basis for financial reporting), a significant amount of assets (for example, accounts receivable and real estate) is related to legal rights, including property rights. In determining the existence of an asset, the property right is not substantial, thus, for example, a leased property is an asset if the business entity controls the benefits that it provides for obtaining from the property. Although the ability of a business entity to control benefits is generally determined by legal rights, however, the item may be 
consistent with the definition of assets even when there is no legal control. For example, the know-how obtained in the course of development may correspond to the definition of an asset if the business entity, while keeping it secret, controls the benefits it hopes to obtain from it. A similar approach should be applied when recognizing a particular element of the financial statements.

In the fourth section of the stated document, in paragraph 40.6 it is said that the economic substance of the transactions must be taken into account, but not only their legal form.

At present, the idea of the predominance of substance over form, what is attributable to the existence of this characteristic in IFRS, is used as a separate principle in the accountinglegislation of many countries (Azerbaijan, Belarus, Armenia, Kyrgyzstan, China, Poland, Hungary, and others) (Lehenchuk, 2011). Referring to the Report on Adoption of IFRS, N.V. Generalova notes that this principle is fixed in the national legislation and the legislation of Moldova (Generalova, 2011).

The system of normative regulation of Ukraine has its analogue. The predominance of substance over form as the principle of accounting and financial reporting is enshrined in Art. 4 of the Law of Ukraine "On Accounting and Financial Reporting in Ukraine". It is enshrined in the National Regulation (Standard) of Accounting 1 "General Requirements for Financial Reporting" as a principle for the preparation of financial statements.

Although the impact of IFRS stipulated a significant extension of the principle of the predominance of substance over form in the world, however, depending on the economic conditions of the country's development, sometimes there are problems with its adoption (Lehenchuk, 2011). The reasons for these problems remain unrevealed, which makes a very complicated process of implementing existing proposals for its implementation in the management practice, including, while conducting an accounting. Only the differences in the system of law are mentioned.

The concept of the predominance of substance over form, for example, in contrast to the concept of conservatism (prudence), is not an inherent characteristic of the national accounting doctrines but differs depending on the peculiarities of the construction of the national accounting systems. In particular, from the approach to their regulation - ruleor principle-oriented. In addition, a significant influence on the application of the principle in foreign countries is carried out by the current system of law (Lehenchuk, 2011).

Two opposed conceptions of capital: property (physical) and resource (financial), as well as the conflict between the two main accounting models: Anglo-American and Continental-European (Ozeran, 2012) are based on the relationship "form - economic substance".
In Ukraine, the papers of S.F. Holov (Holov, 2007), O.M. Petruk (Petruk, 2005; Petruk, 2006), are devoted to the study of this problem, however, an answer that will overcome obstacles to the implementation of the principle of the predominance of substance over form should be found in the economic plane, but not only in the legal. Although in this case, they are essentially intertwined.

\section{Influence of the theory of property rights and agency theory on the accounting methodology}

Aggravation of this problem in the twentieth century led to a number of theoretical studies. So, in the second half of the twentieth century, the theory of property rights that arose in the so-called "economic imperialism", a phenomenon characteristic of the neoclassical analysis, consisting in the desire of the neoclassicists to combine all kinds of sciences on the basis of the neoclassical approach with the use of microeconomic tools. The founders of the theory of property rights are deemed to be R. Coase and A. Alchian. I. Barzel, H. Demsetz, D. North and others were engaged in the subsequent development of this theory.

The theory of property rights, which originates in the Anglo-Saxon theory of law, in contrast to the continental legal system, allows for fragmentation of property rights and recognizes as property objects not only material but also intangible property. At the heart of the theory is the understanding of property rights as a set of individual powers, known as the "bundle" of property rights, the author of which is A. Alchian. The set of the elements of property rights that the entity owns, determines the value of assets. The process of determining the elements of property rights is called the specification of property rights. R. Coase explained this phenomenon so, "If the rights to take certain actions can be acquired or sold, they eventually become those who appreciate the opportunities provided by them. In this process, rights will be acquired, divided, and combined so that the activities provided by them bring the income that has the highest market value" (Coase, 1993). Thus, the main task of the theory of property rights, as Western economists formulate it, consists in analysing the interaction between economic and legal systems.

E.S. Hendriksen and M.F. Van Breda considered features of the influence of legal proprietary aspects on accounting within the legal or judicial theory. "It connects accounting science with civil law, explaining the subject of accounting as the control of rights and obligations of individuals involved in the economic process. Hence the income is not the funds received, but the right to receive them" (Hendriksen, 2000).

This right is built on a methodological basis, which is formed by the theory of rent. "The science of rent is a science of economic causation, which allows us to trace 
products to their sources", - argued J.B. Clark in his famous work (Malyshev, 2012).

Thus, development of property relations contributed to expanding the range of users of accounting information - individuals who got a possibility to formulate goals and objectives of accounting. First of all, it applies to investors who acted directly or through intermediaries in the stock markets. This led to the emergence of various methodological conflicts, primarily associated with the recognition of income, assets, and liabilities.

At the heart of this conflict lies the practical problem of separating the owner and manager. It is the object of studying by the representatives of agency theory. The "positive" theory of relations between agents addresses the problem of "separation of ownership and control", which was formulated by A. Berle and G. Means in the 1930s. Among the leading representatives of this concept are W. Meckling, M. Jensen, Y. Fama. The centre of its attention is the question: what steps are needed to make the behaviour of agents (hired managers) least deviate from the interests of the principals (owners)?" (Chukhno, 2007).

Solving the problems associated with qualitative characteristics of accounting information depends on the implementation of accounting principles, in particular, the principle of the predominance of substance over form. The possibility of its practical application, in our opinion, depends on the implementation of the main provisions and ideas of institutional theory, agency theory and rent theory at the level of accounting methodology.

The practical problems of property relations, as well as theoretical works aimed at their solution based on the methodological basis of agency theory and rent theory, should be considered as the foundation for formation and spread of the principle of the predominance of substance over form.

One of the main consequences of the extension of the principle of substance over form, in particular, due to IFRS, was the change in approaches to asset recognition. The attribute of the control, which is used as a criterion for recognition of assets in accounting, changes, in essence, the economic status of an enterprise, making it the owner or user of resources, in terms of the presence of certain elements of property rights. Accordingly, individual business processes associated with their involvement and use should be considered as rental relations, and recognition of income from them should be considered as a rent.

Taking into account the fact that rent belongs to the factors of production, theoretical studies in this field should be considered as a basis for research on the courses of accounting development, in particular, regarding the principles and criteria for recognition of income and assets.

Advantages of the representatives of agency theory should be used to identify and overcome obstacles in applying the principle of the predominance of substance over form in the management practice. In particular, this applies to the implementation of the requirement for control of the object as a condition for the recognition of assets in accounting.

We agree with the conclusion of I.A. YukhymenkoNazaruk (Yukhymenko-Nazaruk, 2014) on the need to use the provisions of the agency theory to improve the theoretical and methodological foundations of accounting. However, its scope should not only bring up the problem of asymmetry of information and associated transaction costs but also cover the implementation of the principles of accounting, in particular, the principle of the predominance of substance over form.

Thus, the assessment of changes in the environment as factors of development of the accounting methodology should contain the demands of the institutional environment that arise as a result of its development and transformation in addition to studying information requests. Given that, one of the most urgent issues of globalization was and remains the issue of property relations, their development and the requirements that they generate should be taken into account when developing a proposal for the development of accounting methodology. Adaptation of the accounting system to the changes in the environment, in particular, globalization, should take place in line with the practical implementation of existing theoretical approaches to solving the problem of distribution and redistribution of resources, the nature of ownership and use of which has undergone significant changes.

At the level of accounting methodology, it manifests itself in the need to standardize and unify the implementation of the principle of the predominance of substance over form, in particular, regarding the condition of control as one of the main criteria for recognizing objects of accounting. In this case, the subject of accounting should be considered in the interpretation of E.S. Hendrickson and M.F. Van Breda, who understood it through the prism of the interconnection with civil law, namely the control of the rights and obligations of the persons involved in the economic process. Based on this fact, the researchers conclude that income is not the funds received, but the right to receive them. This idea should be the basis for changes in the conceptual approach to income recognition, analysis of its structure, sources of formation, distribution, and redistribution, as well as review on the basis of the theory of rent, which takes into account the above features, the essence of the facts of economic life, consideration of which is one of the main accounting tasks.

The outlined transformation of accounting is able to solve the practical problem of separating the owner and manager, which has received an urgent relevance under the influence of modern processes in the economy in the context of globalization. 


\section{Conclusions}

Development of the processes of globalization was accompanied by substantial transformations of property relations. As a result, approaches to the analysis of activities, in particular, on the use of resources, distribution, and redistribution of incomes have changed. One of the options for solving this problem is the implementation of the principle of the predominance of substance over form in the accounting methodology, in particular, in terms of the control of the recognition of assets. As a result, there will be a certain change in the economic status of an enterprise, making it the owner or user of resources, given the presence of some elements of the property rights. The above stated provides grounds for considering business processes related to the use of certain resources, the manifestation of rent relations, and the recognition of incomes from them as a rent.

To overcome the obstacles in applying the principle of the predominance of substance over form in the management practice at the level of accounting methodology, one should rely on the experience of the representatives of the theory of rent, agency theory, and the theory of institutionalism.

Prospects for further research are to identify the legal prerequisites for rent accounting and to determine the trends of the transformation of the property institution. This will contribute to the significant social and economic development of countries whose economies have long been in the command and administrative management format, as well as the legal recognition of the actually existing economic prerequisites for rent accounting.

\section{References:}

Budkin, V. S. (2006). Suchasni tendentsii vplyvu hlobalizatsii na mizhnarodnu torhivliu [Contemporary trends in the impact of globalization on international trade]. Collection of research papers, issue 48, p. 3-15.

Valuev, B. I. (2016). O nedostatochnoy svyazi nauki o bukhgalterskom uchete s problemami razvitiya tselosnoy sistemy upravleniya [On inadequate communication of accounting science with the problems of development of an integrated system of management]. Ekonomist, 12, p. 58-63.

Halchynskyi, A. S. (2009). Kryza i tsykly svitovoho rozvytku [Crisis and cycles of world development] "ADEF-Ukraine", $392 \mathrm{p}$.

Generalova, N. V. (2011). Preobladanie sushchnosti nad formoy [The predominance of substance over form] Finance and business. № 3. Retrieved from: http://finbiz.spb.ru/download/3_2011/general.pdf

Holov, S. F. (2007). Bukhhalterskyi oblik v Ukraini: analiz stanu ta perspektyvy rozvytku [Accounting in Ukraine: analysis of the status and prospects of development]. Monograph. Centre for Educational Literature, $522 \mathrm{p}$.

Hubskyi, B. V. (2003). Yevroatlantychna intehratsiia Ukrainy [Euro-Atlantic integration of Ukraine]: Logos, 328 p.

Economic Encyclopaedic Dictionary: In 2 Vols. Vol. 1 / Ed. by S.V. Mochernyi. - Lviv: Svit, 2005, 616 p.

Economic Encyclopaedic Dictionary: In 2 Vols. Vol. 2 / Ed. by S.V. Mochernyi. - Lviv: Svit, 2006, 568 p.

Conceptual basis for financial reporting. Retrieved from: http://minfin.gov.ua/control/uk/publish/ article? showHidden $=1 \&$ art_id $=408095 \&$ cat_id $=408093 \&$ ctime $=1423500775962$

Coase, R. (1993). Firma, rynok i pravo [The firm, the market, and the law]. M.: "Delo LTD" with contributions from Publishing House "Catallaxy", $192 \mathrm{p}$.

Kucherenko, T. (2010). Pryntsyp prevaliuvannia zmistu nad formoiu u finansovii zvitnosti [The principle of the predominance of substance over form in the financial reporting]. Herald of KNUTE, № 2, p. 103-113.

Lehenchuk, S. F. (2011). Pryntsyp prevaliuvannia sutnosti nad formoiu: istoriia vynyknennia ta mistse v suchasnii bukhhalterskii doktryni [The principle of the predominance of substance over form: a history of occurrence and place in modern accounting doctrine]. Journal of ZhSTU, №2(56), p. 126-128.

Mazur, V. (2002). Nova kontseptsiia hlobalizatsii ekonomiky [A new concept of globalization of the economy]. Herald of Ternopil Academy of National Economy. P. 234-237.

Malyshev, B. S. (2012). Obshchaya teoriya renty [The general theory of rent]. Tomsk: FJTSU, 196 p.

Nevmerzhytskyi, Ye. V. (2008). Koruptsiia v Ukraini: prychyny, naslidky, mekhanizmy protydii [Corruption in Ukraine: causes, consequences, mechanisms of counteraction]. Monograph, KNT, 368 p.

Nikolaenko A. Indeks globalnogo otstavaniya [Global backlog index]. Retrieved from: http://blogs.eizvestia.com/ full/610-indeks-globalnogo-otstavaniya

Ozeran, A. V. (2012). Prevaliuvannia sutnosti nad formoiu - fundament doviry do finansovoi informatsii? [Is the predominance of essence over form the foundation of trust in financial information?]. Economic strategy and prospects for the development of trade and services. Issue 2, p. 51-57. Retrieved from: http://nbuv.gov.ua $/ \mathrm{j}$-pdf/ esprstp_2012_2_10.pdf.

Petruk, O. M. $(2005)$. Harmonizatsiia natsionalnykh system bukhhalterskoho obliku [Harmonization of national accounting systems]. Monograph. Zh. : ZhSTU, 420 p.

Petruk, O. M. (2006). Rehuliuvannia bukhhalterskoho obliku v Ukraini: teoriia, metodolohiia, praktyka [Accounting regulation in Ukraine: theory, methodology, practice]. Monograph. Zhytomyr: ZhSTU, $152 \mathrm{p}$.

Subotin, A. K. (2004). Granitsy rynka globalnykh kompaniy [Boundaries of the global companies market]. M: Editorial URSS, $328 \mathrm{p}$. 
Suk, P. L. (2011). Pryntsypy bukhhalterskoho obliku [Principles of accounting]. Scientific Herald of NULES of Ukraine, № 168 (1). Retrieved from: http://elibrary.nubip.edu.ua/13248/1/11slp.pdf

Filipenkov, A. S. (2002). Ukraina i svitove hospodarstvo: vzaiemodiia na mezhi tysiacholit [Ukraine and the world economy: interaction on the verge of millenniums]. K.: Lybid, $470 \mathrm{p}$.

Hendriksen, E. S. (2000). Teoriya bukhgalterskogo ucheta [Theory of accounting]. M.: Finance and Statistics, 576 p. Chub, O. O. (2008). Bankivska diialnist u konteksti intehratsii ta hlobalizatsii [Banking activities in the context of integration and globalization]. Finance of Ukraine. № 1, p. 138-146.

Chukhno, A. A. (2007). Suchasni ekonomichni teorii: Pidruchnyk [Modern economic theories: Textbook]. K.: Znannia, 878 p.

Shcherbyna, O. V. (2001). Problemy hlobalizatsii svitovoi ekonomiky [Issues of the globalization of the world economy]. Formation of market relations in Ukraine: Collection of research papers. Issue 12 / SE I.K. Bondar, 168 p. Yukhymenko-Nazaruk, I. A. (2014). Deiaki pytannia rozvytku bukhhalterskoho obliku na osnovi polozhen ahentskoi teorii [Some issues of accounting development based on the provisions of the agency theory]. Issues of the theory and methodology of accounting, control, and analysis, № 1 (28), p. 333-342. 